\title{
News Reflection on Presidential Decree Related to Migrant Workers as Ideological Practice of Global Capitalism in Indonesia
}

\author{
Rahmat Tunny ${ }^{1}$, Henni Gusfa ${ }^{2}$ \\ $\left\{\right.$ rahmatbinayyub@gmail.com ${ }^{1}$, henni.gusfa@gmail.com ${ }^{2}$ \} \\ Universitas Mercu Buana, Indonesia ${ }^{1,2}$
}

\begin{abstract}
Public policies contained in Presidential Regulation No. 20 in 2018 concerning migrant workers issued by President Joko Widodo trigger pros and cons in the development of the global economy and international politics. This study aimed to dismantle the purpose behind Presidential Regulation on migrant workers and the practice of global capitalist ideology through news on online media, particularly Detik.com, Kompas.com and Tempo.co from April to May 2018. The theories used in this Norman Fairclough's principles [1]. The method used in this study was a critical paradigm through Norman Fairclough's critical discourse analysis. The analysis unit of this research was the news about the Presidential Regulation on migrant workers. The results of this study indicated several points. The Government did not dispute the presence of migrant workers from China. There were political interests between the Government and Chinese investors. The media industry applied a global capitalist ideology and a global business model based on international political interests that were more on the scope of the Asia Pacific region. The role of the media, in which at the current condition, supported the policy of the Presidential Regulation on Migrant workers through media report loaded with political interests reflected by policies supports issued by Jokowi.
\end{abstract}

Keywords: News, Foreign Labor, Capitalism.

\section{Introduction}

In communication, it not always solely between humans and humans, but it also exists through text messages. Text is a media product produced by organizational governance in the media industry. Because of that reason, texts with certain media interests has contextual meaning. Texts will become meaningful if it sustains to be manipulated with economics, political situation and power. In this case, media coverage related to the political and cultural economic situation in Indonesia leads to the issue of capitalist economy.

The existence of new media can change the development of information. People do not require a long time to find out the information, to access information, or events that occur around them. The reader only needs a cellphone and internet network to access information. New media's existence at this time does not necessarily erase the confessional ones (printed media, newspapers and magazines). It is solely because in reviewing information, new media (online media) does not digs and publishes deep information resulted in the short length of it spreaded in the public. Whereas printed media, both newspapers and magazines, provide a 
very complete and in depth informationthat the position of the print media is still irreplaceable up until now.

Mass media is a communication channel that reaches a wide capacity of audience and influence public opnions. Today's mass media is not only a forum for information delivery, but has also been used as a business field for businessmen; the beginner and the executive ones. This condition makes the media continue to experience changes that were previously a place to channel information, but also has become a tool for entrepreneurs to mitigate their business matters.

Furthermore, the mass media has an administrative function to strengthen existing social forms [2]. The more complete function of the mass media is to give status to public issues, organizations, and social movements by selecting various issues to be distributed to various layers in public. One of many issues is chosen to be discussed and highlighted. Mass media coverage is full of political interests, usually featuring two dominant groups. This conflict will appear in the mass media based on how they view the reality, background, and their relevant ideology, as well as the journalists covering the news [3]. The media may have a tendency to side with one of the parties or be neutral.

This study discussed the problem of Migrant workers's (MW) existence and position in Indonesia after the issue of Presidential Regulation (PR) No. 20 in 2018. This research focused on report related to PR of MW in three online media, namely Detik.com, Kompas.com and Tempo.co, in which the news were construction and delivered suits their subjective interests and ideology. Detik.com prioritized events in the field in accordance with PR's rules. Detik.com tended to attack the Government more on the issue of migrant workers regulation, problems or incidents that occur in the field, or violations of the law committed by migrant workers themselves as seen in the news on May 30, 2018 with the title 'The Rapid flow of Chinese workers Highlighted by Ombudsman' with unskilled labour or have no expertise to enter Indonesia.

Meanwhile, migrant workers' coverage in Kompas.com online media seemed to put its position in the middle by criticizing the government but at the same time also supported their decision regarding the issue of Presidential Regulation. However, when compared to Tempo.co online media, it seemed to be more supportive of the Government's policy direction related to the issue. In this position, the direction of Tempo.co's news could not be separated from the relationship between media owners, Goenawan Muhamaad and Yusuf Mansur, and the authorities in this country. These two men views had been known to be very liberal and seemed to provide more support to the incumbent government. Based on the issues and cases explained above, the research analyzed Presidential Regulation no. 20 in 2018 about MW and the interests of three online media, Detik.com, Kompas.com and Tempo.co. in reporting MW.

\section{Research Methods}

This research used qualitative method by applying Norman Fairlough's critical discourse analysis approach, in the three initial dimension approach [4][5], Fairclough suggested that there were three dimensions of discourse: text, interaction, and their respective contexts [1]. The analysis by using this approach was carried out in three stages; text analysis, discourse analysis, and social practice analysis. This analytical approach shows that text is the production of communication process, or discursive practices. Text production process includes production, distribution, and consumption throughout discursive practices, all of 
which are influenced or determined by social practices. In other words, the relationship between social practices and texts is mediated by discursive practices through production, distribution, and consumption. The object of this research was the report published by three online media, Detik.com, Kompas.com and Tempo.co, related to PR on MW.

\section{Results and Discussion}

Detik.com's coverage presented more of their position in opposing PR no. 20 in 2018 concerning MW, because the PR was considered to possibly cause problems. Detik.com thought Government was being to linient by giving more space for migrant workers to easily enter Indonesia. This could threaten the position of local workers who were currently unemployed and jobless.

In terms of vision, Detik.com had different way from Kompas.com and Tempo.co. In the discourse of news text analysis, there is object analysis that combines insights from social constructionist and news-making approaches with analysis of linguistic and social cognition. This approach claims that negative report is only part of the results of routine conditions mentioned in news reports. Of course, the fact that information must be presented in a condensed and abbreviated way requires selection, summary, and generalization operations [6].

The news discourse itself is a social and cognitive practice. Negative report is produced by (reproduction) dominant ideologies encoded in the structure (content and style) of news texts [7][3]. More specifically, discourse analysis states that text and speech play an important role in reproduction. Judging from the discourse developed by Detik.com, this discourse, indeed, couldnot be seperated from how the media produced news. It was also related.

This inseparable situations on how the media produced news positions and Detik.com made news content like that were because its owner's political direction was not in line with the incumbent government. Its economic context was also different. So, the context of news production was also different from th current politics context since the owner himself had a different political affiliation from the Government or President Joko Widodo himself. When it was viewed from political affiliation as explained earlier, the Chairperson of the Democratic Party, Susilo Bambang Yudhoyono (SBY), had a close relationship with Detik.com and in 2019 Presidential Election, SBY supported Prabowo Subianto-Sandiaga Uno, and this was counted as the political context. Therefore, this siituation was related to the news production that made the news coverage being produced was also different.

If it was viewed from macro point, we will picture the ideology of global capitalism that SBY built through Detik.com. This news was related to global capitalists because SBY's international politics had never had a significant closeness to China from the beginning, especially since SBY's background was military. SBY was more affiliated to America, so global capitalism which was previously created during Jokowi's era was more directed towards China. Whereas, SBY as a former military who had also received special military training in America was not in a close relationship to China.

The discourse of capitalism that stretches from the time of mercantilism to the current consumption society cannot be separated from the existence of human beings who tend to be individualistic and full of themselves. The strength of the global macroeconomy is also pushing the mass media not only as a means of conveying capitalist ideology but also as an obedient institution to become an actor to accumulate profits and capital expansion [8]. In 
addition, another reason for SBY not being too close to China was seen after SBY was elected President of Indonesia in 2004. He immediately made his first state visit to America and received an award from the American Government because he was considered an American military alumni who became President in Asian countries, and this was also considered as global interest.

At the beginning, Kompas.com's coverage was so contra-related to the Presidential Regulation and the presence of MW, just as Vice President Jusuf Kalla responded. However, the direction of Kompas.com's coverage remained more of on a balanced position. It also did not provide sharp criticism of the government's decision on the issue of the MW Regulation. Kompas.com owners were not too pro-government, although it was closer to the Government but it did not become so critical of the issue of MW in Presidential Regulation. Kompas.com seemed to be more of economic interested in its media (Kompas Group) to reporting PR of MW which was the main issue that did not disrupt the media business.

Fairclough sees a productive link in CDA on theoretical claim of cultural political economy which the economic system is politically embedded, and that both political and economic objects are built socially [1][9]. This social construction is partly a discursive process and as such CDA offers itself as an important analytical tool to cover the languagerelated aspects of the phenomenon on political-economic globalization (Discourse, Berlin). Since, in addition to its media, Kompas also had other ongoing businesses such as hotels, book production, printing and others. So, they also wanted to have a safe business which made MW's Presidential Regulation legalization goes well.

The political economic approach focused on the study of the relationship between the structure of the political economy, the dynamics of the media industry, and the ideology of the media itself. The attention of political economy research is directed at ownership, control and operational strength of the media market. From this point of view, mass media institutions are seen as an economic system that is closely related to the political system. The critical political economy perspective also fully analyzes public intervention as a process of legitimacy through public disputes regarding the forms of conflict that must be taken because of capitalist efforts to narrow the space for public discourse and representation [10].

Kompas.com actually worked on economic situation included in liberal economy. It was seen in how Kompas.com thought about the sustainability of the company's business and its network. In terms of its ideology, the closeness between the owner of Djakop Oetama and the incumbent Government can be seen from the ideology of President Soekarno's Indonesian National Party (PNI). That the establishment of Kompas media was inseparable from the commitment of President Soekarno. This was also the reason for Kompas.com's close relationship with the incumbent Government. So, Kompas.com was not too sharp in criticizing because its owner had global economic interests. The new-liberalism in Kompas.com was also seen from Kompas.com's relationship with Soekarno's PNI ideology which was aniveliated with the Indonesian Democratic Party of Struggle.

Although Tempo.co's coverage appeared to be balanced or cover both side in terms of the selection of sources, in Tempo.co's report on the Regulation of the TKA, it gave a lot of space to the Government to convince the public that the Regulation of the MW was not a threat. Cover both sides themselves in journalistic terminology simply means balanced, and the simple meaning of balanced in Indonesian Dictionary (KBBI) was the same weight, impartial and/or neutral.

The owner of Tempo.co himself had an affiliation or closeness with President Jokowi personally, and that was seen from the production of news or discourse, as well as how Tempo.co developed the discourse. Foucault views discourse as a practice and system of 
representation and the idea of power relations is the significance of the focus in Foucault's approach to discourse analysis. This Foucault approach tries to understand how individuals see the world and study categorization, personal relationships, institutional, ideological, and political [11][12]. From this point of view, the point was already different. Detik.com was more on the political direction, Kompas.com was on the economic interests and Tempo.co was more on the affiliation or closeness of the owner with President Jokowi.

Tempo.co actually supported liberalism, although the medium did not seem to refer or be directly affiliated with China, but more on the closeness of Goenawan Mohammad to President Jokowi. Media studies in developing countries tended to emphasize the dominance or hegemony of Government power, where media was used as a means of nation propaganda or an interesting instrument to preserve the ruling ideology (hegemony). In this case, there was significant interest from the power holders to use the media as a political tool in achieving their goals. Besides having a closeness with Jokowi, Goenawan Mohammad himself had a closeness with the Indonesian Solidarity Party (PSI) which also supported Jokowi in 2019 Presidential Election.

\section{Conclusion}

Whereas the direction of reporting from these three online media could be seen in their differentiation, the different attitudes towards Presidential Regulation No. 20 in 2018 and the reporting of MW were as followed:

1. Detik.com was more critical of the issue of the PR on MW and concerned more on the interests of the media owners, Kompas.com was more balanced in terms of news in order to safeguard the company's business, and Tempo.co was more in favor of the Government for the interests of media owners and companies.

2. From the description above why the media was more critical, balanced and impartial because this was inseparable from the interests of the owner relating to news production.

3. Why did these three media make one policy, or editor, or framing undergo such diverieansiasi was because this was inseparable from the interests of the global capitalist economy itself.

\section{References}

[1] N. Fairclough, Critical Discourse Analysis: The Critical Study of Language. New York: Longman, 1995.

[2] B. Sardar, Ziauddin; Van Loon, Membongkar Kuasa Media. Terjemahan oleh Dina Septi Utami. Yogyakarta: Resist Book, 2008.

[3] P. Yazgan and D. E. Utku, "News discourse and ideology: critical analysis of Copenhagen gang wars' online news," Migr. Lett., vol. 14, no. 1, pp. 145-160, 2017.

[4] M. Jørgensen and L. J. Phillips, Analisis Wacana: Teori \& Metode. Pustaka Pelajar, 2007.

[5] Eriyanto, Analisis wacana: pengantar analisis teks media. LKiS Yogyakarta, 2001.

[6] K. Liu and F. Guo, "A review on critical discourse analysis," Theory Pract. Lang. Stud., vol. 6, no. 5, pp. 1076-1084, 2016.

[7] T. A. Van Dijk, "Media contents The interdisciplinary study of news as discourse," in $A$ handbook of qualitative methodologies for mass communication research, Routledge, 2002, pp. 122-134. 
[8] M. K. Putra, Y. Djuy, and L. Mani, "News Content Perspective of TV One and Metro TV in Seeing Indonesia Government Policy," Glob. Media J., vol. 15, no. 29, pp. 1-5, 2017.

[9] A. Saraswati, "Wacana Perlawanan Persebaya 1927 terhadap PSSI: Analisis Wacana Kritis Norman Fairclough,” Mozaik Hum., vol. 17, no. 2, pp. 181-191, 2018.

[10] A. Iqbal and M. Haqnawaz, "Semiotics and Critical Discourse Analysis of "The Hero; love story of a spy,"” Int. Res. J. Arts Humanit., vol. 43, no. 43, 2016.

[11] C. Nazzaro, M. Lerro, M. Stanco, and G. Marotta, "Do consumers like food product innovation? An analysis of willingness to pay for innovative food attributes," Br. Food J., 2019.

[12] J. Asghar, "Thou shalt not think: Editors' voice in an English textbook to propagate vested agendas," Educ. Res. Int., vol. 2014, 2014. 